\title{
Study on the Present Study Situation of Japanese Taboo
}

\author{
Yaping Zhang \\ Yan’an University, Yan’an, Shaanxi, 716000
}

Keywords: Japanese, Taboo, Present Study Status

\begin{abstract}
With the progress of the times, is considered to be the ancient society or the backward society of the uncivilized society taboo customs, for most people in modern society, is already more and more alienated. Today, human civilization is highly developed, whether the taboo has been abandoned? Based on the viewpoints and methods of linguistics and folklore, the author makes an investigation and analysis of the causes of the existence of taboo in Japanese through an interview survey conducted in Japan.
\end{abstract}

\section{Introduction}

From the surface of the surface, the taboo is a kind of ignorant and backward religious nature of the culture, which has a historical and cultural value and scientific research value. The study of taboos involves the important disciplines of folklore, linguistics, and so on. Through the study of taboos, it can not only understand the present situation of social culture and the attitude of the prohibition of taboo in the taboo language, you can also see the inheritance of modern culture for ancient culture. It can be said that the taboo language with the development of human history and development, is an indispensable language of human language and culture, taboo as a rather religious language field has been deeply integrated into the human social life. For the study of Japanese language and culture, the study of taboo in Japanese is also the study of Japanese characteristics of social culture, because in order to understand a particular language and culture, we must understand the language of the taboo.

\section{Analysis of the Causes of Japanese Taboos}

Japanese people enjoy the natural environment to bring them a wonderful experience, from their culture which can be seen that they enjoy the natural things. The most famous of the Japanese culture is the cherry blossom culture, the spring tree full of cherry blossoms soaked throughout Japan, the whole of Japan became the pink petals of the ocean. The Japanese think that cherry blossoms are nature giving them the best gift, thinking cherry trees have their own souls. At the same time, the Japanese for autumn leaves and winter snowflakes have a strong sense of worship, that any natural things have their own Reiki. The Japanese believe that the human language and cherry blossoms, maple leaves, snowflakes, like these natural things, is a soul without their own people are given the desired items, the Japanese believe that their language has its own aura, once the taboo words There may be a variety of disasters. Therefore, to protect themselves from the impact of the disaster is necessary to respect the spirit of nature, do not say the destruction of Aura vocabulary, the destruction of the natural spirit of the act to be stopped.

Japanese contains many Chinese characters, which are from the ancient Chinese culture in the past, the same, Japanese pronunciation of many words are pronounced English transliteration, which shows the Japanese ability to accept foreign culture is very strong. Japanese people in the language to accept foreign culture, the same taboo language also accepted the different languages of the taboo language culture. For example, the taboo number in Western Christianity is "13", because "13" is considered the devil Satan's day, so Western Christianity is extremely taboo "13" figure, that "13" is a symbol of bad luck and disaster. Although there are Christians in our country, but this taboo in Christianity and has not become a culture of our country, most Chinese people do not taboo 
"13" this figure. However, in the language of Japan, "13" has become a taboo of Japanese language, it is because the Japanese believe that even if they do not believe in Christian Islam should be taboo is likely to appear bad luck, would rather believe it, not credible The ability to think and accept foreign cultures has created a wide range of Japanese taboos.

Japanese attention to etiquette is also widely known, in the course of the Japanese tourism will find a variety of Japanese rituals need to be careful in the conversation process to prevent the occurrence of violations of the Japanese ritual. Japanese ceremonies include Japanese kimono, Japanese social etiquette, ancient Japanese traditions, etc. are preserved and inherited very well. Many of the ancient taboo have been completely inherited down, become a modern life to escape the scourge of a language etiquette culture. For example, the ancient culture does not like camellia, that camellia in the litter is not a piece of litter, but the whole flower suddenly completely landing is very unlucky. At the same time that the cyclone to spend in Japanese pronunciation when the word is similar to death, although the modern culture has no camellia and cyclamen to spend unlucky statement, but when the patient is still taboo gift and talk about camellia and Cyclamen flowers. Such as the birth and death of important occasions in the traditional rituals are more abundant, these traditions bring taboo is also very rich, festive ceremony (marriage, children, etc.) can not say with "dead" "end" and other moral is not good of the taboo language, in the sad ritual (funeral) can not say that with the joy of taboo, these taboos with the Japanese culture has been for many years, has become a Japanese culture.

\section{Taboo in Modern Japanese Life}

Some of the earliest Japanese taboos are derived from the production activities of the backward science and technology to the ancient Japanese in the production of dangerous activities in the possibility of great, especially in the mountains hunting or hunting in the sea of special production activities Prone to unpredictable danger. Therefore, before going out of production activities, there are many can not say the taboo. For example, Japan's "animal taboo" is the mountain hunting may encounter dangerous animals to avoid taboo, this type of taboo gradually become a professional taboo within the job. In today's various occupations, the commercial ban on the Japanese language more business operations with the market supply and demand changes in the strong, so in the commercial field of the taboo is more sensitive. The taboo of the news industry is also a lot, many of which are related to the war after the war with the words of war have become a taboo language. For example, the term "tribe" in the Sino-Japanese war itself is not derogatory in Japanese, but in the Sino-Japanese war, the use of contaminated Chinese insult is gradually becoming a taboo.

People's life from birth to adult ceremony, marriage, death and other important stages of life have a corresponding etiquette, where the baby was born and married because they are very festive moments are taboo taboo. In the wedding, there can not be "do not "dead na and other words exist in the sad words; in the funeral can not appear return "(repeated) this word, can not have any happy words and so on. The taboo of ritualism is the most content of the taboo language. As the Japanese respect the tradition and inherit the traditional national character, the taboo of rituals does not decrease with the development of society, but is well preserved Down, these words in a variety of people who have a good expression of the rituals.

\section{Japanese view of nature}

The Japanese are very natural, love nature. The attitude towards nature is to emphasize the integration of nature with nature rather than putting nature on the opposite of mankind as the object of victory. Although typhoons, earthquakes and other natural disasters continue, but nature also to Japan to provide a very cute, worthy of praise of the natural environment. Japanese cherry in the spring, autumn leaves reward, winter snow, never tired. People tend to think that this is the gift of the gods. The biological nature of the biological, non-biological treatment, fantasy every flower, each grass has a god to dominate, this pantheistic thought even to the modern society has also been inherited. In this interview survey, asked the Japanese taboo concept, many people said, "believe 
that language spirit", "a flower of a grass, all things have gods exist." It can be seen that the Japanese "natural view" is also a good soil of all things in the modern life.

Through the interview we learned that the modern Japanese daily life of the taboo of the number of signs of increase. Which both the traditional concept of digital taboo, but also by the impact of the West and the new digital taboo. For example, the "13" taboo is undoubtedly influenced by the Christian culture. Western culture on the number "13" taboo, is probably well known, but the acceptance of different degrees in China and Japan. The "13" taboo in China did not become a cultural consensus. While the Japanese said that even if not Christians, would rather believe it. Since you know this taboo, you have to avoid. From which we can peek into the Japanese people are easy to accept the national culture of foreign culture.

From the survey was informed about the mobile phone number, car culture, as well as the test system and other taboo expression is the traditional society did not have the past. They are taboo expressions that are produced in the context of urbanization and are closely related to modern lifestyles. Especially in recent years with the taboo language both linked and different from the taboo of the "homophonic" phenomenon "language Lu Weiguan" is very popular. For example, the Japanese presented a five-dollar coin. "Five yen" and pronunciation of the same, that cherish the fate of meaning. "The bream" The pronunciation of this fish is popular because people are easy to think of the word. Every time during the examination, clever use of "wins and other good words to name the candy sales particularly good, probably because people believe that "language together" will bring good luck, believe in the power of the language. "Language Lu together homophonic game prevalence, indicating that the language of faith still has a certain impact. People with half of the game half of the mentality of the game to see the taboo words, which can also be seen as a feature of urban folk.

In this survey of Japanese taboo, the most taboo is mentioned as a taboo about weddings and funerals in life etiquette. In addition, the ritual manual devoted to the rituals of life is also the most common. Japanese "crown wedding funeral" also refers to the life of the most significant in the "birth ceremony", "adult ceremony", "wedding" and "funeral" four ceremony. "Four Rites" is different from the daily life, especially and serious moments. Therefore, although the modern Japanese way of life has basically been Westernized, but held "crown wedding funeral" ceremony or more choice of traditional Shinto, Buddhist ritual. From the emphasis on the etiquette of life, reflecting the Japanese emphasis on tradition, adhere to the traditional mentality and did not change with the modern way of life changes.

\section{Conclusion}

Although with the development of the times, the continuous progress of science and technology, many taboo language have been diluted, no longer through taboo to fully sustenance of their own expectations. But the taboo language as a folk culture, embodies the spirit of the people of all the pure spirit, embodies the people expect to change the daily life of the difficult attitude of adversity. The taboo in Japanese expresses the language and culture of Japanese, and it can also reflect Japanese morality from some daily taboos, which is of great significance to the study of Japanese culture.

\section{Acknowledgements}

Subject: 2018 Shaanxi Provincial Department of Education special research project "Japanese taboo alienation phenomenon of cognitive analysis"

\section{References}

[1] Gao Shaojun. Intercultural communication on English and Chinese taboos and its translation strategies [J]. Western Leather. 2016 (08)

[2] Jin Jingai. English and Chinese taboo language pragmatic function and its cultural comparison 
[J]. Inner Mongolia University for Nationalities. 2005 (02)

[3] Tang Su Min. Comparison of cross-cultural perspective of Chinese and foreign taboos comparison [J]. Popular arts. 2017 (18)

[4] Rao Fei. Archetypal theory under the theory of English language, taboo language analysis [J]. Young writers. 2017 (26)

[5] Li Wen. Analysis of Chinese and English animal taboo [J]. Campus English. 2017 (29)

[6] Wang Tao. English taboo [J]. Guangdong Peizheng University Journal. 2007 (04) 